\title{
Bee Flora Diversity in Dhenkanal District of Odisha
}

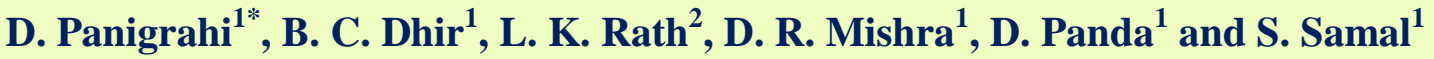 \\ ${ }^{1}$ Regional Research Technology Transfer Station, Mahisapat, (OUAT), \\ Dhenkanal 759013, India \\ ${ }^{2}$ Department of Entomology, OUAT, BBSR, India \\ *Corresponding author
}

\begin{abstract}
A B S T R A C T
Keywords

Bees, Diversity, Flora, Pollen, Nectar

Article Info

Accepted:

28 August 2020

Available Online:

10 September 2020

Field investigations were carried out for four years from April, 2016 to March, 2020 to record the total bee flora and to identify the most important among them in Dhenkanal district of Mid- Central table land zone of Odisha. All plant species recorded under this study were found to provide either nectar or pollen or both to different species of bees. The bee species collected both nectar and pollen from 79 plants, nectar only from 13 plants and pollen only from 3 plants. Out of the total bee flora, 14 were observed to be major and 10 as medium considering plant density per unit area, flowers per plant, duration of blooming and time of attraction of these species to the bees.

Introduction

Among the various good qualities of insect, the most important one is that it helps in pollination of flowering plants which leads to increase in yield, an uniform crop, improvement in quality of seeds and fruits and hence takes a key role for existence of mankind. According to Carruth (1950), 5 per cent of the flowering plants are self pollinated and the rest 95 per cent are cross pollinated out of which 10 per cent depend on wind and 85 per cent on insects pollination. Among the pollinating insects, honeybees are the most important and their role in increasing the yields of various crops has been well

recognised (Teale, 1957). An Estimate of 2500 plant species are being effectively pollinated by bees. However, the crops those are mostly pollinated by insects are tomato, melon, pumpkin, cucumber, cowpea, pea, bean, squash among vegetables; apple, pear, orange, peach, cherry, plum, raspberry, grape fruit, lemon and fig, among the fruit crops, alfalfa, soybean, clover and cotton among other crops; (Pradhan, 1991) and sunflower, safflower, mustard, Niger, sesame are among the oilseed crops (Rao et al., 1980). The experimental findings reported from U.S.A., U.K., and U.S.S.R. indicated that bee pollination can increase the yield up to 33000 per cent over self pollination in crops like
\end{abstract}


bean, clover, berseem and Lucerne. If bees or other pollinators are not available they cannot and do not set seeds or fruits (Anonymous, 1985). Also honeybees and other pollinators are of immense importance for ecological safety and economic security systems due to its pollination activities. Human food security and bio-diversity are profoundly dependent on pollinators (Brodschneider and Crailsheim, 2011; Tautz and Heilmann, 2007). Over the past 200 million years, flowers and their pollinators have evolved in parallel (Maheswari, 2003). In a 2007 assessment of the scientific data on the issue, the UN environment program observed; Any loss in biodiversity is a matter of public concern but losses of pollinating insects may be particularly troublesome because of the potential effects on plant reproduction and hence on food supply security.

The basic foods sources of honeybees are nectar and pollen (Weidenmullar and Tautz, 2002; Jha and Vandermeer, 2009) of which nectar is transformed into honey. Pollen and honey are stored in the hive for future use. Honey and pollen production mainly depend on the abundance of bee flora, bee pastures and their attractiveness to honeybees (Williams and Carneck, 1994 and Laven et al., 2005). Hence the quantity and quality of bee flora in a particular region or place determines the extent of success of bee keeping and it varies in different agroclimatic conditions (Panigrahi, 2013). Also the duration of flowering period and hence the availability of nectar and pollen determines the suitability of the area for bee keeping (Panigrahi, 2011). Dhenkanal District of MidCentral Table Land Zone of Odisha has been very congenial for bee keeping, but due to changed climatic condition (rise in temperature) and dry summer, the bee colonies are diminishing in many areas and the number of bee forging plants are reducing day by day. The beekeepers practicing bee keeping with Apis cerana indica are getting comparatively lower quantities of honey (of average $3-4 \mathrm{~kg} /$ box/year as against potentiality of $10-12 \mathrm{~kg}$ under stationary condition) due to lack of knowledge and interest in migrating honey bee colonies which has compelled many beekeepers to leave this low cost enterprise. The migration of the honey bee colonies to diversified bee pasturages not only increases the quantity and quality of honey, but also provides better returns to the bee keepers. Keeping these points in mind, the present investigation was carried out through intensive survey of Dhenkanal district of Odisha for four consecutive years from Apri, 2016 to March, 2020 to determine the availability of bee flora, duration of flowering and their role in provision of either nectar, pollen or both.

\section{Materials and Methods}

The present investigation was undertaken in all the 8 blocks of Dhenkanal district by choosing 3 places from Dhenkanal Sadar $\left(20^{\circ}\right.$ $39^{\mathrm{l}} \mathrm{N}$ and $\left.85^{0} 35^{\mathrm{l}} \mathrm{E}\right)$, Bhuban $\left(20^{0} 52^{\mathrm{l}} \mathrm{N}\right.$ and $85^{0}$ $\left.49^{\mathrm{l}} \mathrm{E}\right)$, Parajang $\left(20^{0} \quad 54^{\mathrm{l}} \mathrm{N}\right.$ and $\left.85^{0}{ }^{1} 8^{\mathrm{l}} \mathrm{E}\right)$, Kankadahada $\left(21^{0} \quad 05^{1} \mathrm{~N}\right.$ and $\left.85^{0} \quad 34^{1} \mathrm{E}\right)$, Kamkshyanagar $\left(20^{0} \quad 55^{\mathrm{l}} \mathrm{N}\right.$ and $\left.85^{0} \quad 33^{\mathrm{l}} \mathrm{E}\right)$, Odapada $\left(20^{0} 45^{\mathrm{l}} \mathrm{N}\right.$ and $\left.85^{0} 25^{\mathrm{l}} \mathrm{E}\right)$, Gondia $\left(20^{0} 46^{\mathrm{l}} \mathrm{N}\right.$ and $\left.85^{0} 48^{\mathrm{l}} \mathrm{E}\right)$, Hindol $\left(20^{0} 36^{\mathrm{l}} \mathrm{N}\right.$ and $85^{0} 12^{\mathrm{l}} \mathrm{E}$ ) having potential bee flora over four years from April-2016 to March-2020. Seasonal plants were characterized by taking observations on bee activity pertaining to collection of Nectar / Pollen or both during the flowering period of each individual plant species. Different plant species depending upon their blooming period were visited individually between commencements and cessation of flowering. The plant species were listed based on the source for which they were visited by bees like nectar $(\mathrm{N})$, pollen $(\mathrm{P})$ ore both $(\mathrm{N}+\mathrm{P})$. The observations on bees were recorded within three kilometres radius of the above places for all the three species of honey 
bees viz. Apis cerana indica, Apis dorsata, Apis florea on all the plant species. The pollen and nectar collectors can be observed by the method mentioned below. The pollen collectors come and land on the petals. Bees hold the anthers and collect pollen with help of mandibles and first pair of legs. The pollen is being transferred to the pollen baskets while moving to other anthers and also to other flowers. The nectar collectors bend over the anther and stigma, collect nectar from nectaries. Sometimes they collect nectar by inserting the proboscis between the petals sideways. These bees do not touch the anther and stigma and do not contribute for pollination. unlike other bees. Apis florea was noted to spend the longest period of time as compared to Apis cerana indica and Apis dorsata respectively for collection of nectar and pollen. Observations on the three bee species Apis cerana indica, Apis dorsata and Apis florea were taken at hourly intervals from 9:00 AM till 4:00 PM, and it was found that maximum number of bees were found to be observed in between 11:00 AM to 12:00 PM, and lowest numbers in between 3:00 PM to $4: 00 \mathrm{PM}$.

The flower visiting bees such as Apis cerana indica, Apis dorsata and Apis florea were collected by using an insect hand-net bearing diameter of $30 \mathrm{~cm}$. Sweeps were made throughout the flowering period of the specific flora and collection was started one week after commencement of flowering till $90 \%$ flowers came up in the plants. In the present investigation for convenience and proper study eight calm, clean sunny days in the peak period of flowering (PPF) were chosen for each flora. At least fifteen bees of each species were observed for recording the time spent to insert the proboscis and suck up the nectar for nectar collection or brushing was recorded for pollen collection. There was not a single species of Apis melifera in the collected samples because it has not yet been introduced in any of the eight blocks of the district. The order of bee visitation on individual plant species was determined on the basis of the actual number of individual bee species per unit area. The species which visited in highest numbers was mentioned first followed by those in decreasing order.

\section{Results and Discussion}

The observations recorded on the presence of bee flora in all the eight blocks are enumerated in Table-1. The critical study of the data revealed that all the (79) plant species were observed to be visited by different bee species during different parts of four years of study. Majority of plants (62) were recorded as both nectar and pollen $(\mathrm{N}+\mathrm{P})$ yielder, followed by only nectar (14) and pollen (3) yielder. The preference of visitation by bees however, varied with the individual species on different plants of the various species preferentially by Apis cerana indica (Fabricius) followed by A. dorsata (Fabricius) and Apis florea (Fabricius). Out of the total flora listed in Table-1, only (14) were observed to be major flora owing to plant density/ unit area, flowers/plant, duration of blooming. Also these species attracted bees over a longer period and provided nectar/pollen for a longer duration. Considering the above points in mind, babul, begunia (vitex), brinjal, eucalyptus, green gram, jamun, karanj, lantana, maize, neem, palas, sal and sesamum were considered to be major flora whereas arhar, ber, coriander, cotton, gram, kanchan, mahul, okra, sisoo and toria, as medium and all other plants were considered as minor bee foraging plants.

The period from November to April can be regarded as the major floral period of this region for the build up of bee colonies and subsequently for honey flow. The period is marked by the blooming of major flora like babul, ber, brinjal, cashew, cucurbitaceous 
vegetables, eucalyptus, green gram, karanj, lantana, mahul, maize, mango, neem, palas, sesamum, sisoo and tomato. All these plants are naturally occurring in abundance either as cultivated or forest plants in the area. Though some of the above flowering plants come into blooming in November or December, but due to cold weather and cloudy days the bees are not able to exploit these sources. But when weather slightly warms up, bees start visiting the source enormously. Similar type of observations was also made by Atwal et al (1970) at Ludhiana, Garg (1989), Sharma and Gupta (1993) in Sirmaur and Solan areas, respectively of Himanchal Pradesh. The present study in relation to the visit of $A$. cerana indica, A. dorsata and A. florae to different cereals, oilseeds, pulses, vegetables, fruits, forest and other plants corroborates the findings of Panigrahi (2011) at Angul and
Panigrahi (2013) at Subarnapur districts of Odisha. Panda (1990) at Phulbani district of Odisha also observed the above bee species visited oilseed crops like mustard, sesamum. Sunflower, safflower and niger. The present study in relation to the visit of $A$. dorsata to $\mathrm{Bt}$ and non-Bt cotton corroborate the finding of Mohapatra and Nayak (2012) in Kalahandi, the visit of $A$. cerana indica and $A$. dorsata to mustard, radish, brinjal, cowpea, marigold, mango and cashew corroborate the finding of Patanaik et al., (2012), to rapeseed and mustard is in consonance with the finding of Padhi (2007), to arhar is in consonance with the finding of Padhy et al., (2018) under Bhubaneswar condition and to bael corroborates the finding of Satpathy and Chandra (2016) under Faizabad (UP) condition.

Table.1 Bee flora and its availability in Dhenkanal District of Odisha

\begin{tabular}{|c|c|c|c|c|c|}
\hline $\begin{array}{l}\text { Common name \& Scientific } \\
\text { name }\end{array}$ & Family & $\begin{array}{c}\text { Flowering } \\
\text { period } \\
\text { (months) }\end{array}$ & $\begin{array}{l}\text { Order of } \\
\text { bee sp. } \\
\text { Visitation }\end{array}$ & Sources & Habit \& Nature \\
\hline \multicolumn{6}{|l|}{ Cereals } \\
\hline Maize, Zea mays & Poaceae/Graminae & 3 & $\mathrm{c}, \mathrm{d}, \mathrm{f}$ & $\mathrm{P}$ & Herb, C \\
\hline \multicolumn{6}{|l|}{ Oilseeds } \\
\hline $\begin{array}{l}\text { Sesamum, Sesamum } \\
\text { indicum }\end{array}$ & Pedaliaceae & 3 & $c, d, f$ & $\mathrm{~N}+\mathrm{P}$ & Herb, C \\
\hline $\begin{array}{l}\text { Toria, Brassica campestris } \\
\text { var.Toria }\end{array}$ & Cruciferae & 1 & $\mathrm{c}, \mathrm{d}, \mathrm{f}$ & $\mathrm{N}+\mathrm{P}$ & Herb, C \\
\hline Mustard, Brassica juncea & Cruciferae & 1 & $\mathrm{c}, \mathrm{d}, \mathrm{f}$ & $\mathrm{N}+\mathrm{P}$ & Herb, C \\
\hline $\begin{array}{l}\text { Sunflower, Helianthus } \\
\text { annaus }\end{array}$ & Asteraceae & 2 & $\mathrm{c}, \mathrm{d}, \mathrm{f}$ & $\mathrm{N}+\mathrm{P}$ & Herb, C \\
\hline $\begin{array}{l}\text { Groundnut,Arachis } \\
\text { hypogeae }\end{array}$ & Papilionaceae & 3 & $\mathrm{c}, \mathrm{d}, \mathrm{f}$ & $\mathrm{N}$ & Herb, C \\
\hline \multicolumn{6}{|l|}{ Pulses } \\
\hline Arhar, Cajanus cajan & Papilionaceae & 2 & $\mathrm{c}, \mathrm{d}, \mathrm{f}$ & $\mathrm{N}+\mathrm{P}$ & Herb, C \\
\hline Gram, Cicer arietinum & Papilionaceae & 2 & $\mathrm{c}, \mathrm{d}, \mathrm{f}$ & $\mathrm{N}+\mathrm{P}$ & Herb, C \\
\hline Greengram,Vigna radiate & Papilionaceae & 3 & $\mathrm{c}, \mathrm{d}, \mathrm{f}$ & $\mathrm{N}+\mathrm{P}$ & Herb, C \\
\hline Blackgram, Vigna mungo & Papilionaceae & 2 & $c, d, f$ & $\mathrm{~N}+\mathrm{P}$ & Herb, C \\
\hline Peas,Pisum sativum & Papilionaceae & 1 & $\mathrm{c}, \mathrm{d}, \mathrm{f}$ & $\mathrm{N}+\mathrm{P}$ & Herb, C \\
\hline $\begin{array}{l}\text { Horsegram, Dolichos } \\
\text { billorus }\end{array}$ & Leguminaceae & 1 & $\mathrm{c}, \mathrm{d}, \mathrm{f}$ & $\mathrm{N}+\mathrm{P}$ & Herb, C \\
\hline Vegetables & & & & & \\
\hline
\end{tabular}




\begin{tabular}{|c|c|c|c|c|c|}
\hline $\begin{array}{l}\text { Cauliflower,Brassica } \\
\text { oleraceae var. botrytis }\end{array}$ & Cruciferae & 4 & $\mathrm{c}, \mathrm{d}, \mathrm{f}$ & $\mathrm{N}+\mathrm{P}$ & Herb, C \\
\hline Brinjal, Solanum melongena & Solanacea & 12 & $\mathrm{~d}, \mathrm{c}, \mathrm{f}$ & $\mathrm{N}+\mathrm{P}$ & Herb, C \\
\hline Onion, Allium cepa & Liliaceae & 2 & $\mathrm{~d}, \mathrm{c}, \mathrm{f}$ & $\mathrm{N}+\mathrm{P}$ & Herb, C \\
\hline Garlic, Allium sativum & Liliaceae & 2 & $\mathrm{~d}, \mathrm{c}, \mathrm{f}$ & $\mathrm{N}+\mathrm{P}$ & Herb, C \\
\hline Carrot, Daucus carota & Umblliferae & 2 & $\mathrm{~d}, \mathrm{c}, \mathrm{f}$ & $\mathrm{N}+\mathrm{P}$ & Herb, C \\
\hline Cucurbitaceous vegetables & Cucurbitaceae & 12 & $\mathrm{~d}, \mathrm{c}, \mathrm{f}$ & $\mathrm{N}+\mathrm{P}$ & Climbers, W/C \\
\hline $\begin{array}{l}\text { Amaranthus, Amaranthus } \\
\text { spp }\end{array}$ & Amaranthaceae & 3 & $\mathrm{~d}, \mathrm{c}, \mathrm{f}$ & $\mathrm{N}$ & Herb,C/W \\
\hline $\begin{array}{l}\text { Corriander, Coriandrum } \\
\text { sativum }\end{array}$ & Umblliferae & 3 & $\mathrm{f}, \mathrm{c}, \mathrm{d}$ & $\mathrm{N}+\mathrm{P}$ & Herb, Spice \\
\hline Radish, Raphanus sativus & Cruciferae & 2 & $\mathrm{c}, \mathrm{d}, \mathrm{f}$ & $\mathrm{N}+\mathrm{P}$ & Herb \\
\hline $\begin{array}{l}\text { Okra, Abelmoschus } \\
\text { esculentus }\end{array}$ & Malvaceae & 2 & $\mathrm{c}, \mathrm{d}, \mathrm{f}$ & $\mathrm{N}+\mathrm{P}$ & Herb \\
\hline $\begin{array}{l}\text { Tomato, Lycopersicom } \\
\text { esculentum }\end{array}$ & Solanaceae & 7 & $\mathrm{~d}, \mathrm{c}, \mathrm{f}$ & $\mathrm{N}+\mathrm{P}$ & Herb, C \\
\hline Beans & Papilionaceae & 1 & $\mathrm{c}, \mathrm{d}, \mathrm{f}$ & $\mathrm{N}+\mathrm{P}$ & Herb, C \\
\hline $\begin{array}{l}\text { Drumstick, Moringa } \\
\text { oleiferae }\end{array}$ & Moringaceae & 2 & $\mathrm{c}, \mathrm{d}$ & $\mathrm{N}+\mathrm{P}$ & Tree,C \\
\hline $\begin{array}{l}\text { Potatao, Solanum } \\
\text { tuberosum }\end{array}$ & Solanaceae & 1 & $\mathrm{c}, \mathrm{d}, \mathrm{f}$ & $\mathrm{N}+\mathrm{P}$ & Herb, C \\
\hline Cowpea, Vigna unguiculata & Papilonaceae & 1 & $\mathrm{c}, \mathrm{d}, \mathrm{f}$ & $\mathrm{N}+\mathrm{P}$ & Herb, C \\
\hline Chilli, Capsicum annum & Solanaceae & 1 & $\mathrm{C}, \mathrm{d}, \mathrm{f}$ & $\mathrm{N}+\mathrm{P}$ & Herb, C \\
\hline $\begin{array}{l}\text { Bell peper Capsicum } \\
\text { frutescence }\end{array}$ & Solanaceae & 1 & $\mathrm{C}, \mathrm{d}, \mathrm{f}$ & $\mathrm{N}+\mathrm{P}$ & Herb, C \\
\hline Sweetpotato, Ipomea batatas & Convovulace & 2 & $\mathrm{c}, \mathrm{d}, \mathrm{f}$ & $\mathrm{N}+\mathrm{P}$ & Herb, C \\
\hline \multicolumn{6}{|l|}{ Fruits } \\
\hline Mango,Mangifera indica & Anacardiaceae & 3 & $\mathrm{c}, \mathrm{d}, \mathrm{f}$ & $\mathrm{N}$ & Tree,C \\
\hline Lime, Citrus aurantii swing & Rutaceae & 2 & $\mathrm{~d}, \mathrm{c}, \mathrm{f}$ & $\mathrm{N}+\mathrm{P}$ & Tree,C \\
\hline Lemon,Citrus limon & Rutaceae & 2 & $\mathrm{~d}, \mathrm{c}, \mathrm{f}$ & $\mathrm{N}+\mathrm{P}$ & Tree,C \\
\hline Orage, Citrus cinensis & Rutaceae & 2 & $\mathrm{~d}, \mathrm{c}, \mathrm{f}$ & $\mathrm{N}+\mathrm{P}$ & Tree,C \\
\hline $\begin{array}{l}\text { Batapi, Citrus } \\
\text { grandis/maxima }\end{array}$ & Rutaceae & 2 & $\mathrm{~d}, \mathrm{c}, \mathrm{f}$ & $\mathrm{N}+\mathrm{P}$ & Tree,C \\
\hline Litchi, Litchi chinensis sonn & Sapindaceae & 2 & $\mathrm{c}, \mathrm{d}, \mathrm{f}$ & $\mathrm{N}+\mathrm{P}$ & Tree,C \\
\hline Anar, Punica granatum L. & Punicaceae & 2 & $\mathrm{c}, \mathrm{d}, \mathrm{f}$ & $\mathrm{P}$ & Shrub/Tree,Fruit(W/C) \\
\hline Papaya, Carica papaya & Caricaceae & 2 & $c, d, f$ & $\mathrm{~N}$ & Fruit, $\mathrm{C}$ \\
\hline Guava, Psidium guajava & Myrtaceae & 2 & $\mathrm{c}, \mathrm{d}, \mathrm{f}$ & $\mathrm{N}+\mathrm{P}$ & Tree,C/W \\
\hline Jamun, Syzigium cumini & Myrtaceae & 2 & $\mathrm{~d}$ & $\mathrm{~N}+\mathrm{P}$ & Tree \\
\hline Ber, Zizyphus jujube & Rhamnaceae & 3 & d & $\mathrm{N}$ & Tree \\
\hline Banana, Musa spp. & Musaceae & 3 & $\mathrm{~d}$ & $\mathrm{~N}+\mathrm{P}$ & Tree,C \\
\hline $\begin{array}{l}\text { Cashew, Annacardium } \\
\text { occidentale }\end{array}$ & Anacardiaceae & 2 & $\mathrm{c}, \mathrm{d}, \mathrm{f}$ & $\mathrm{N}+\mathrm{P}$ & Tree,C \\
\hline \multicolumn{6}{|l|}{ Forest Plants } \\
\hline Palas, Butea monosperma & Fabaceae & 3 & $\mathrm{c}, \mathrm{d}, \mathrm{f}$ & $\mathrm{N}+\mathrm{P}$ & Tree,fuel,W \\
\hline Neem, Azadiactha indica & Meliaceae & 2 & $\mathrm{c}, \mathrm{d}, \mathrm{f}$ & $\mathrm{N}+\mathrm{P}$ & Tree,fuel,Medicinal \\
\hline Shisam, Dalbargia sisoo & Papilionaceae & 2 & $\mathrm{~d}, \mathrm{f}$ & $\mathrm{N}+\mathrm{P}$ & Tree,Timber,W \\
\hline Berna, Crataeva religiosa & Capparidacae & 2 & $\mathrm{c}, \mathrm{f}$ & $\mathrm{N}+\mathrm{P}$ & Tree \\
\hline Siris, Albizzea lebbek & Mimosaceae & 2 & $\mathrm{~d}, \mathrm{c}, \mathrm{f}$ & $\mathrm{N}+\mathrm{P}$ & Tree,Fodder \\
\hline
\end{tabular}




\begin{tabular}{|c|c|c|c|c|c|}
\hline Arjun,Terminalia arjun & Combretaceae & 2 & $\mathrm{~d}, \mathrm{c}, \mathrm{f}$ & $\mathrm{N}+\mathrm{P}$ & Tree,Medicinal \\
\hline Harar, Terminalia chebula & Combretaceae & 2 & $\mathrm{~d}, \mathrm{c}, \mathrm{f}$ & $\mathrm{N}+\mathrm{P}$ & Tree,Timber,Medicinal \\
\hline Babul,Acacia arabica & Mimosaceae & 4 & $\mathrm{~d}, \mathrm{f}$ & $\mathrm{N}+\mathrm{P}$ & Tree,Timber \\
\hline Khair,Acacia catechu & Mimosaceae & 2 & $\mathrm{~d}, \mathrm{f}$ & $\mathrm{N}$ & Tree,Timber,Fodder,W/C \\
\hline Simili,Bombax ceiba & Bombaceae & 2 & $\mathrm{~d}, \mathrm{c}, \mathrm{f}$ & $\mathrm{N}$ & Tree,fuel, $\mathrm{W}$ \\
\hline Karanja,Pongamia glabra & Fabaceae & 2 & $d, c, f$ & $\mathrm{~N}$ & Tree,fuel,W \\
\hline Sal,Shorea robusta & Dipterocarpaceae & 2 & $\mathrm{~d}, \mathrm{c}, \mathrm{f}$ & $\mathrm{N}$ & Tree,Timber \\
\hline $\begin{array}{l}\text { Mahul,Madhuca } \\
\text { indica/latifolia }\end{array}$ & Sapotaceae & 2 & $\mathrm{~d}, \mathrm{c}, \mathrm{f}$ & $\mathrm{N}$ & Tree,Timber \\
\hline Behera, Terminalia ballerica & Combritaceae & 2 & $\mathrm{~d}, \mathrm{f}$ & $\mathrm{N}+\mathrm{P}$ & Tree,Medicinal \\
\hline $\begin{array}{l}\text { Eucalyptus, Eucalyptus } \\
\text { cypriota }\end{array}$ & Mimosaceae & 6 & $\mathrm{~d}, \mathrm{c}, \mathrm{f}$ & $\mathrm{N}+\mathrm{P}$ & Tree,Fuel,Medicinal C/W \\
\hline Fasi, Anogeissus latifolia & Combritaceae & 2 & $\mathrm{~d}, \mathrm{c}, \mathrm{f}$ & $\mathrm{N}$ & Tree,Timber C/W \\
\hline $\begin{array}{l}\text { Tamarind, Tamarindus } \\
\text { indica }\end{array}$ & Fabaceae & 2 & $\mathrm{~d}, \mathrm{c}, \mathrm{f}$ & $\mathrm{N}+\mathrm{P}$ & Tree,Fuel \\
\hline \multicolumn{6}{|l|}{ Other Plants } \\
\hline Begunia, Vitex negundo & Verbanaceae & 6 & $\mathrm{~d}, \mathrm{f}$ & $\mathrm{N}+\mathrm{P}$ & Tree,Medicinal (W) \\
\hline $\begin{array}{l}\text { Gulmohr, Jacorana } \\
\text { mimoifolia }\end{array}$ & Bigoniaceae & 2 & $\mathrm{~d}, \mathrm{c}$ & $\mathrm{N}$ & $\begin{array}{c}\text { Tree,Ornamental,Herb } \\
\text { (W) }\end{array}$ \\
\hline $\begin{array}{l}\text { Congressgrass, Parthenium } \\
\text { histophorus }\end{array}$ & Asteraceae & 3 & $\mathrm{~d}, \mathrm{c}, \mathrm{f}$ & $\mathrm{P}$ & Herb,Medicinal \\
\hline Tulsi,Ocimum sanctum & Labiatae & 3 & $\mathrm{~d}, \mathrm{c}, \mathrm{f}$ & $\mathrm{N}+\mathrm{P}$ & Bush/Shrub,Medicinal \\
\hline $\begin{array}{l}\text { Lantana,Lantana camara } \\
\text { Hook }\end{array}$ & Verbinaceae & 3 & $\mathrm{~d}, \mathrm{c}, \mathrm{f}$ & $\mathrm{N}+\mathrm{P}$ & Herb,Ornamental(W/C) \\
\hline Marigold,Tagetes errecta & Asteraceae & 4 & $\mathrm{~d}, \mathrm{c}, \mathrm{f}$ & $\mathrm{N}$ & $\operatorname{Herb}(\mathrm{W})$ \\
\hline $\begin{array}{l}\text { Wild marigold,Tagetes } \\
\text { ninuta }\end{array}$ & Asteraceae & 4 & $\mathrm{~d}, \mathrm{c}, \mathrm{f}$ & $\mathrm{N}$ & Shrub(W/C) \\
\hline Basanga,Adhatoda vasiaca & Leguminaceae & 2 & $\mathrm{~d}, \mathrm{c}$ & $\mathrm{N}+\mathrm{P}$ & Tree,Ornamental (C) \\
\hline $\begin{array}{l}\text { Bottle brush,Callistemon } \\
\text { lanceolatus }\end{array}$ & Myrtaceae & 6 & $\mathrm{~d}, \mathrm{c}$ & $\mathrm{N}+\mathrm{P}$ & Tree,Ornamental (C/W) \\
\hline Kanchan,Bauhinia varigata & Caesalpiniaceae & 2 & $\mathrm{~d}, \mathrm{c}$ & $\mathrm{N}+\mathrm{P}$ & $\operatorname{Herb}(\mathrm{C} / \mathrm{W})$ \\
\hline Golmohar, Delonix regia & Caesalpiniaceae & 2 & $\mathrm{~d}, \mathrm{c}$ & $\mathrm{N}+\mathrm{P}$ & Tree,Ornamental (C) \\
\hline $\begin{array}{l}\text { Harsingar,Lagerstromia } \\
\text { indica }\end{array}$ & Lythraceae & 3 & $\mathrm{~d}, \mathrm{c}$ & $\mathrm{N}+\mathrm{P}$ & Wild Herb(W) \\
\hline $\begin{array}{l}\text { Touch me not, Mimosa } \\
\text { pudica }\end{array}$ & Asteraceae & 3 & $\mathrm{~d}, \mathrm{c}$ & $\mathrm{N}+\mathrm{P}$ & Wild Herb(W) \\
\hline Raintree, Samonia saman & Fabaceae & 2 & $\mathrm{~d}, \mathrm{c}$ & $\mathrm{N}+\mathrm{P}$ & Tree $(\mathrm{C} / \mathrm{W})$ \\
\hline $\begin{array}{l}\text { Palm tree, Prichardia } \\
\text { grandis }\end{array}$ & Palmaceae & 2 & $\mathrm{~d}, \mathrm{c}$ & $\mathrm{N}+\mathrm{P}$ & Tree(C/W) \\
\hline Tridax, Tridax procumbens & Asteraceae & 2 & $\mathrm{~d}, \mathrm{c}$ & $\mathrm{N}+\mathrm{P}$ & Wild Herb(W) \\
\hline Jatropa, Jatropa curcas & Euphorbiaceae & 4 & $\mathrm{~d}, \mathrm{c}$ & $\mathrm{N}+\mathrm{P}$ & Wild Herb(W) \\
\hline Wild cotton, Gossypium spp. & Malvaceae & 2 & $\mathrm{~d}, \mathrm{c}$ & $\mathrm{N}+\mathrm{P}$ & Wild Herb(W) \\
\hline $\begin{array}{l}\text { Wild Sesamum, Sesamum } \\
\text { spp. }\end{array}$ & Pedaliaceae & 2 & $\mathrm{~d}, \mathrm{c}$ & $\mathrm{N}+\mathrm{P}$ & Climber(C/W) \\
\hline $\begin{array}{l}\text { Bougainvillaea, } \\
\text { Bougainvillaea spp. }\end{array}$ & Nytaginaceae & 2 & $\mathrm{~d}, \mathrm{c}$ & $\mathrm{N}+\mathrm{P}$ & Climber(C/W) \\
\hline
\end{tabular}

d- A. dorsata, c-A. cerana indica, f-A.florea, N-Nectar, P-Pollen, C-Cultivated, W-Wild 
The study indicated that $A$. dorsata visited almost all the important flora in moderate numbers whereas A. cerana indica visited Palas, eucalyptus, neem, karanj, sesamum, toria and cucurbitaceous vegetables in large numbers. However, A. florea outnumbered all other species on mango, litchi, brinjal, tomato, sisso and babul. Surplus honey period from bee keeping view point was observed in the months of January and February for the domestic species $A$. cerana indica and wild species $A$. dorsata and A. florea. During this period the bee keepers and local farmers extracted maximum amount of honey from the hives of domestic species and nests of the above two wild species, respectively. Summer season is marked by the blooming of palas, jamun, bhindi, arjun and some cucurbitaceous vegetables which provide sufficient flora for the bees after the decline of flowering in toria, sunflower, sesamum, blackgram, eucalyptus in winter months. Though the rainy and autumn (July-Oct) is characterized by blooming of major sources like maize, tulsi, pudina, babul etc. but these are not found as better nectar sources and the bees thrive on the stored nectar or by artificial sugar fed by bee keepers during this period and can be termed as dearth period. The observations also revealed that a large number of bees die because of pesticidal poisoning when bees visited vegetables like brinjal, tomato, beans etc. Under these circumstances, the bee keepers and the vegetable growers should have amicable understanding and accordingly the pesticide spray schedule and opening of hives should be arranged by the vegetable growers and bee keepers respectively.

The results pertaining to the number of bee foraging plants, the sources of nectar and pollen and their time and duration of blooming can be very useful for the bee keepers to plan their bee keeping activities with respect to spraying by vegetable growers and migration in such a way that they avoid over dependence of a particular area where they keep their bee boxes through utilization of forage sources present in the nearby areas to fetch sustainable income. Also the vegetable growers should plan for their spraying schedule according to the flowering period of major bee foraging cultivated and other plants to avoid poisoning of the bees and management in the death period. Accordingly the beekeepers can plan to migrate their colonies to places having appropriate bee flora at appropriate time to get more honey and hence more returns.

\section{References}

Anonymous.1985. Annual report 1984-85. Dept. entomol. Apic. HPKVV, Solan, Himahal Pradesh, India, pp. 98.

Atwal, A.S., Bains, S.S. and Singh, B.1970. Bee flora for four species of Apis at Ludhiana. Indian Journal of Entomology, 32: 330.34.

Brodschneider, R. and Crailsheim, K. 2011. Volkerverlus ederhonigbiene:

Risikofaktorenfur die bestaubungssicherheit in Osterreich. Entomologica Austriaca 18:73-86.

Carruth, L. A. 1950. Fundamental Principles of Pollination. Iowa State Apiarist Report: 65-67.

Garg, R. 1989. Bee flora of Paunta Valley. Indian Bee Journal 51: 1314

Jha, S. and Vandermeer, J.H. 2009. Contrasting bee foraging in response to resource scale and local habitat management. Oikaos 118: 1174-80.

Laven, I., Boot, V.W.J., Mutsaers, M., Segeren, P. and Velthuis, H. 2005. Beekeeping in the Tropics (Agrodok 32) Wageningen. $6^{\text {th }}$ Edition $86 \mathrm{p}$.

Maheswari, J.K.2003.Endangered Pollinators, Enviro. News. Vol 9 No 1- January 2003 (International Society for Environmental Botanist http//isebindia.com/01_04/03-01- 
3.html).

Mohapatra, L.N. and Nayak, S.K.2012. Studies on foraging activity of Rock Bee Apis dorsata Fab. On Bt and NonBt Cotton Hybrids. National Symposium on Eco-friendly Approaches to Pest Management for Sustainable Agriculture.24-25 November, 2012:170-171.

Padhi, J.2007.Enhancing seed yield of Rapeseed and Mustard through Insect Pollination. National Symposium on Sustainable Pest Management for safer Environment, 6-7, December,2007:pp180.

Padhy, D.,Mohapatra, R.N. and Satapathy, C.R.2018. Pollinator complex and their contribution to yield of Pigeon pea Cajanus cajan L. in Odisha. Journal of Plant Protection and Environment 15(2):55-57.

Panda, P. N. 1990. Foraging behavior and pollination efficiency of different bee species in oil seed crops in Phulbani district of Odisha Ph.D thesis submitted to O.U.A.T., B.B.S.R., Odisha.

Pangrahi, D. 2011. Diversity of bee flora and its time of availability in Angul district of Odihsa. Green farming 2: 106-08.

Pangrahi, D.2013. Diversity of bee flora and its availability in Subarnapur District of Odisha. Journal of Insect Science 26 : 192-196.

Patnaik, H.P., Satapathy, C.R.and Panda, N.N. 2012. Prevalence, species richness and diversity of Flower visiting Insects at Bhubaneswar, Odisha. Journal of Plant Protection and Environment 9(1):1-10.

Pradhan, S. 1991. Agricultural entomology and pest control by Shri Uma Shankar, Under secy. for the publication and information division at ICA, New Delhi, pp. 267.

Rao, G.M.; Suryanaraya, M.C. and Thakar, C.V. 1980. Bees can boost oil seed production. Indian farming 29(11): 2526.

Satpathy, S.N. and Chandra, U.2016. Pollination efficiency of Insect Pollinators on Aegle marmelos correa at Kumarganj, Faizabad. National Symposium on New Horizon in Pest Management for Sustainable Developmental Goals. 23-24, December, 2016: pp. 185-186.

Sharma, H. and Gupta, J. K. 1993. Diversity and density of bee flora of Solan region of Himachala Pradesh (India) Indian Bee Journal 55: 9-20.

Tautz, J. and Heilmann, H.R. 2007. Phanomenhonigbiene Spektrum Verlag, Heidelberg: pp 26-27, 56-59.

Teale, E. W. 1957. Insect Friends. Dodd Mead \& Co., New York, pp. 96.

Weidenmuller, A. and Tautz, J. 2002. In hive behavior of pollen foragers (Apis mellifera) in honeybee colonies under conditions of high and low pollen need. Ethology 108: 205-21.

Williams, I. H. and Carneck, N. L. 1994. Land use changes and honeybee forage plants, pp. 7-20. In: Matheson A (ed.) Forage for bees in an Agricultural Landscape. IBRA, Cardiff.

\section{How to cite this article:}

Panigrahi, D., B. C. Dhir, L. K. Rath, D. R. Mishra, D. Panda and Samal, S. 2020. Bee Flora Diversity in Dhenkanal District of Odisha. Int.J.Curr.Microbiol.App.Sci. 9(09): 3649-3656. doi: https://doi.org/10.20546/ijcmas.2020.909.450 